\title{
Badania przesiewowe w kierunku wykrywania raka stercza. Aktualny stan wiedzy i argumenty za skriningiem
}

\author{
Andrzej Stelmach, Łukasz Wohadlo
}

\section{Screening for prostate cancer: current knowledge and arguments confirming it's value}

Poprawa ochrony zdrowia w ostatnich dekadach powoduje wydłużenie życia i starzenie się społeczeństwa, jednak pociąga za sobą rosnące koszty leczenia. Częstość oznaczania poziomu PSA wpływa na wzrost wskaźnika wykrywalności zachorowań na raka stercza (RS). Był on drugim co do częstości zachorowań i szóstą przyczyną zgonów z powodu nowotworów złośliwych na świecie w 2008 roku. Przed wprowadzeniem PSA dominowały rozpoznania zaawansowanych przypadków RS. W USA w 1988 roku RS miejscowo zaawansowanego (T3-4) rozpoznano u 55,5\% badanych, zaś w 2005 tylko u 8,4\%. W USA skrining PSA jest często stosowany, i w chwili rozpoznania stwierdza się tylko 4\% rozsianych raków stercza. Omówione badania kliniczne i metaanalizy dostarczają argumentów zarówno za, jak i przeciw skriningowi. Podstawowy cel skriningu, czyli wzrost wykrywalności RS i spadek śmiertelności z tego powodu najczęściej został osiągnięty, jednak okupiony nadwykrywalnością, nadmiernym leczeniem oraz wzrostem powikłań i kosztów z tego powodu. Ocena indywidualnego ryzyka i nomogramy pozwalają na indywidualny skrining. AUA rekomenduje skrining u dobrze poinformowanych mężczyzn, rozpoczynający się po 40 rż. Zalecenia EAU na rok 2013 dotyczące skriningu w raku stercza rekomendują skrining powszechny u bezobjawowych mężczyzn w wieku 50-70 lat oraz skrining oportunistyczny, który obejmuje indywidualne postępowanie i jest inicjowany przez pacjenta i/lub lekarza. Punktami końcowymi obu typów skriningu jest redukcja śmiertelności z powodu raka stercza. Aktualnie wyzwanie dla skriningu RS to zmniejszenie nadwykrywalności i ograniczenie nadmiernego leczenia oraz wynikających z tego powikłań.

NOWOTWORY Journal of Oncology 2013; 63, 6: 486-492

\section{Wprowadzenie}

Przyczyną dyskusji o badaniach przesiewowych w raku stercza (RS) jest poprawa ochrony zdrowia w ostatnich dekadach, co powoduje wydłużenie życia i starzenie się społeczeństwa, jednak pociąga za sobą rosnące koszty leczenia. Częstość oznaczania poziomu PSA wpływa na wzrost wykrywalności zachorowań na RS. Trwają dyskusje czy skrining populacyjny RS powinien być trwałym elementem polityki
zdrowotnej.W tej debacie na pierwszy plan wysuwa się ocena zysków i strat z powodu skriningu [1]. W Europie dąży się do wypracowania wspólnej polityki badań przesiewowych stercza, ponieważ jest taki sam dostęp do oznaczania PSA i taka sama jakość leczenia raka stercza jak w USA (Manifest EURO-UOMO) [2]. Rak stercza (RS) jest nowotworem, którego najwyższa zachorowalność przypada u mężczyzn na wiek 65-79 lat (szczyt w wieku 70-74 lat). W badaniach

Centrum Onkologii — Instytut im. Marii Skłodowskiej-Curie, Oddział w Krakowie

Wystąpienie podczas I Konferencji Naukowej czasopisma Nowotwory „Debaty onkologiczne” 5-6 kwietnia 2013 roku 
autopsyjnych stwierdzono RS u mężczyzn w wieku 51-60 lat w prawie $50 \%$ przypadków, a w wieku powyżej 80 lat — w powyżej $80 \%$ przypadków. Można przyjąć, że zgodnie z danymi z roku 1993 cytowanymi przez Sakra i wsp. co drugi 60-latek miał raka stercza. Najczęściej, bo w 77,7\% przypadków rozpoznawano raka stercza z wynikiem Gleason Score (GS) wynoszącym 5-6 punktów dzięki biopsji gruboigłowej oraz w 48-59\% przypadków - podczas badania pośmiertnego [3, 4]. Zgodnie z danymi Krajowego Rejestru Nowotworów, prowadzonego przez Instytut Onkologii w Warszawie, w roku 2008 zachorowalność na raka stercza wynosiła 8268 przypadków, a śmiertelność - 3892 chorych. W Polsce co 1 godzinę dochodzi do nowego zachorowania, zaś co 2 godziny stwierdzamy kolejny zgon chorego na raka stercza [5]. Według badania Eurocare-3 z roku 1994 w Europie średnie przeżycia 5-letnie wynosiły 65\% (czyli co trzeci chory umiera), a w Polsce przeżycia 5-letnie dotyczyły około $40 \%$ chorych.

Dane epidemiologiczne na świecie przedstawiają się następująco: RS jest po raku płuca drugim co do częstości występowania, a nowe zachorowania wynoszą rocznie 903 500. Jest szóstą przyczyną śmiertelności z powodu nowotworów złośliwych i na świecie; w 2008 roku 258400 chorych umarło z powodu raka stercza [1].

Argumentem przemawiającym za skriningiem RS jest epidemiologia - jest najczęściej rozpoznawanym rakiem w krajach zachodnich i stanowi 3. przyczynę zgonu (po raku płuca i raku jelita grubego). Ryzyko zachorowania w USA wynosi 15,8\%, a ryzyko zgonu - 2,8\%, zaś w Europie odpowiednio $9 \%$ i 3,1\%. Jest rakiem rzadko rozpoznawanym w wieku poniżej 55 lat. Tylko wcześnie rozpoznany, ograniczony do narządu RS jest potencjalnie wyleczalny. Wykryty w fazie objawowej jest najczęściej zaawansowany i nieuleczalny $[1,2,4]$.

\section{Era PSA}

Przed erą PSA badanie per rectum (DRE) nie przyczyniło się do poprawy wykrywalności wczesnego raka stercza. DRE poprawiło specyficzność w wyższych zakresach stężeń PSA. Analizując naturalny przebieg RS, należy stwierdzić, że wczesny RS jest bezobjawowy. Późno wykryty rak stercza, czyli w fazie objawów klinicznych, jest najczęściej chorobą śmiertelną [6, 7]. W badaniach z roku 1980 przy rozpoznaniu raka w 30\% przypadków występowały już przerzuty do kości (Moss), a w 50\% przypadków występowały przerzuty do węzłów chłonnych $(\mathrm{N}+)$. Na 2-3 mężczyzn, którzy zachorowali, 1 umierał na chorobę uogólnioną. Jest to argument za skriningiem. Kiedy zaczęła się umowna era PSA, można było mówić o epidemii raka stercza. Maksymalną częstośćzachorowań w USA odnotowano w roku 1992 i wynosiła ona 210/100 000 (179/100 000 — rasa biała i 250/100 000 — rasa czarna) [8].

Mimo wzrostu zachorowań nie wzrosła śmiertelność (ryc. 1).

W prospektywnym badaniu (Catalony) u 6630 mężczyzn powyżej 50 lat w 1994 roku stwierdzono RS ograniczonego do narządu u 70-85\% chorych w przypadku stosowania skriningu (DRE + PSA), oraz w 30\% przypadków, jeżeli skrining nie był stosowany $[9,10]$. W Japonii oznaczenie PSA w skriningu jest rzadko stosowane, dlatego stwierdza się w 70\% przypadków raki miejscowo zaawansowane. Dane epidemiologiczne potwierdzają, że efektem wprowadzenia w 1986 PSA do skriningu RS jest migracja zawansowania klinicznego choroby. O ile w 1988 roku RS miejscowo zaawansowanego (T3-4) rozpoznawano u 55,5\% badanych, to w 2005 - tylko u 8,4\%. W USA skrining PSA jest często stosowany i w chwili rozpoznania stwierdza się jedynie 4\% rozsianych raków stercza. Utarło się tam określenie „efekt PSA", gdyż od roku 1992 śmiertelność z powodu raka stercza spadła o 39\%. Badania SEER i NCHS w USA, oparte na badaniu poziomu PSA w skriningu, wykazały spadek śmiertelności z powodu raka stercza o 16,1\% u rasy białej i o 10,9\% u rasy czarnej $[11,12]$. Czy w takim razie PSA jest markerem idealnym? Nie, ponieważ cechuje się dużą specyficznością tkankową, natomiast niską specyficznością kliniczną. W badaniu z roku 2004 około 1/4 chorych z rozpoznaniem raka stercza miała prawidłowy poziom PSA [13]. Jeżeli PSA nie

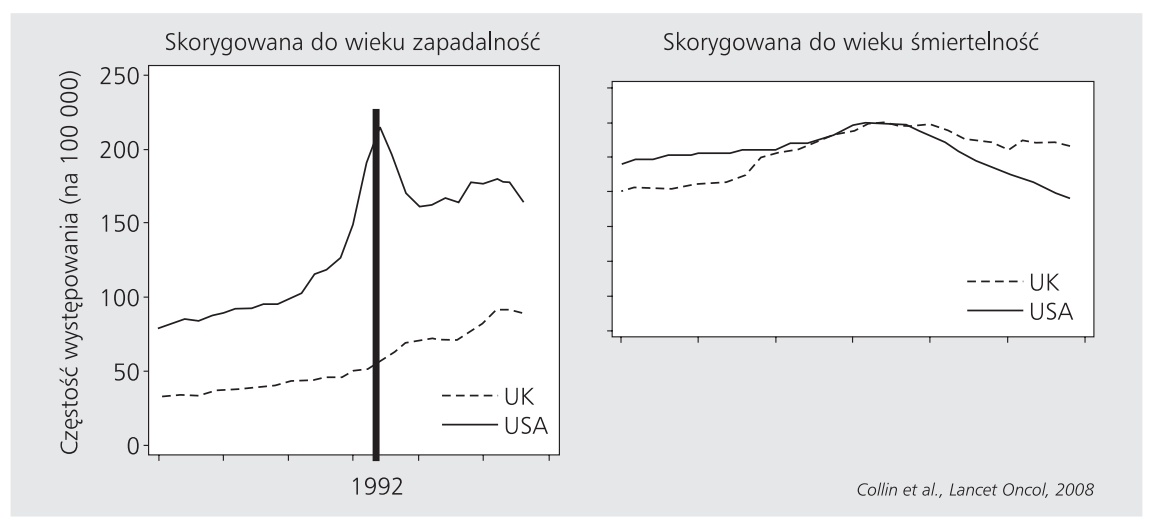

Rycina 1. Zachorowalność i śmiertelność z powodu RS w latach 1975-2008 w USA i Wielkiej Brytanii 
jest markerem idealnym i ma swoje ograniczenia (czułość i specyficzność), to jak poprawić wykrywalność raka stercza i jak odróżnić przypadki istotne klinicznie od tych, które nie wymagają natychmiastowego leczenia?

\section{Skrining raka stercza}

Definicja idealnego skriningu to badania przesiewowe mające zapobiegać śmierci z powodu zaawansowanej choroby poprzez efektywne leczenie jej wczesnych stadiów. Problemami związanymi z badaniami skriningowymi są: nadmierna wykrywalność (overdetecting — przypadki niewykryte przy braku skriningu) oraz nadmierne leczenie (overtreatment - leczenie przypadków nieistotnych klinicznie), generujące duże koszty, oraz objawy uboczne. Idealny skrining (wg Andermana i wsp.) powinien odpowiadać rozpoznanym potrzebom. Cel skriningu trzeba ustalić na początku działania i należy zdefiniować populację docelową. Efektywność skriningu musi być udowodniona naukowo, program powinien obejmować edukację, badania, leczenie kliniczne i zarządzanie programem. Należy zapewnić gwarancję jakości poprzez mechanizmy minimalizujące ryzyko związane ze skriningiem oraz zapewnić świadomy wybór, niejawny i z poszanowaniem autonomii badanego. Skrining powinien być sprawiedliwy i równo dostępny dla całej populacji docelowej, a ocenę skriningu powinno się planować od początku. Całkowite korzyści ze skriningu powinny przewyższać związane z nim szkody. W literaturze żaden skrining nie spełniał tych wszystkich warunków. Przeprowadzone dotychczas kontrolowane badania kliniczne [15-22] dostarczają argumentów za skriningiem RS, takich jak poprawa przeżywalności (mocne dowody - ERSPC), wykrywanie choroby w niższym stadium zaawansowania (mocne dowody), możliwa poprawa jakości życia (jak dotychczas - brak dowodów). Oszacowanie ryzyka poprzez określenie progu poziomu PSA, izoformy PSA, narastanie poziomu PSA oraz zidentyfikowanie raka niskiego ryzyka i możliwość prowadzenia aktywnej obserwacji pacjentów z rakiem niskiego ryzyka ma ograniczone dowody. Ale są też argumenty przeciw skriningowi, takie jak nadwykrywalność (overdetecting) i nadmierne leczenie (overtreatment), które mają mocne dowody, podobnie jak powikłania i koszty.

Z powodu powyższych argumentów wprowadzone zostało pojęcie aktywnego skriningu. Pozwala on na uniknięcie nadmiernego leczenia niezaawansowanego raka stercza lub raka o wolnej progresji, a tym samym uniknięcie niepotrzebnych przypadków obniżenia jakości życia. Nie powinniśmy pytać czy, ale jak i kogo włączyć do programu badań. Parametrami wykorzystywanymi w aktywnym skriningu w celu wykrycia raka o niskim ryzyku są: PSA $<10 \mathrm{ng} / \mathrm{ml}$; gęstość PSA (PSAD) < 0,2; PSA-DT (podwojenie poziomu) > 3 lat; DRE cT1, cT2a; Gleason score do $3+3=6(3+4=7)$; dodatnie biopsje max w 2 rdzeniach (<50\%). Postępowanie nazwane aktywnym skriningiem jest obserwacją z odroczeniem leczenia radykalnego, podejmowane z intencją wyleczenia chorego [23, 24].

W badaniu z roku 2010 badającym aktywny skrining u pacjentów ze stabilną chorobą, z rakiem stercza niskiego ryzyka (M0, Gl < 7), przyczyną rozpoczęcia leczenia radykalnego było: w 50\% przypadków PSA DT < 3 lata, w 42\% PSAD > 2, w 38\% PSA > 10 ng/ml. Czas obserwacji w tym badaniu wynosił 10 lat [23]. W wytycznych NCCN (National Comprehensive Cancer Network) z roku 2010 określono kryteria rozpoznania raka stercza o niskim ryzyku (T1 c/T2a, $\mathrm{PSA}<10 \mathrm{ng} / \mathrm{ml}, \mathrm{Gl}<7$ ) oraz raka stercza o bardzo niskim ryzyku (T1c, PSAD <0,15, Gl < 7, < 3 biopsje z rakiem, < 50\% zajęte przez raka).W zaleceniach określono, że w przypadku oczekiwanego czasu przeżycia chorego poniżej 20 lat i raka o bardzo niskim ryzyku zaleca się aktywny skrining $[1,7,9]$.

\section{Przegląd badań naukowych dotyczących skriningu w raku stercza}

W ostatniej dekadzie nastąpił prawdziwy "wysyp" artykułów i wyników randomizowanych badań klinicznych dotyczących skriningu w raku stercza.

\section{Badanie w Tyrolu - Austria}

Nierandomizowany skrining populacyjny wprowadzono w 1993 roku, uzyskując do 2008 roku spadek śmiertelności z 20,4/100 tys. do 9,0/100 tys. [15, 16]. Podobny efekt obserwowano w badaniach w USA, Wielkiej Brytanii i we Francji $[1,2,8]$.

\section{Badanie Quebec}

Prowadzone w latach 1988-1999, objęło 31133 mężczyzn w grupie badanej i 15353 w grupie kontrolnej w wieku 45-80 lat. Badanie DRE wykonywano na pierwszej wizycie, punkt odcięcia PSA $3 \mathrm{ng} / \mathrm{ml}$. W 11-letniej obserwacji uzyskano redukcję śmiertelności z powodu RS o 62\%. Wyniki kwestionowano z powodu metodologii badania $[2,3,17]$.

\section{Badanie Norrkoping}

Prowadzone od 1987 roku, objęło 1494 mężczyzn w grupie badanej i 7532 w grupie kontrolnej w wieku 50-69 lat. Badanie DRE wykonywano na pierwszej wizycie, punkt odcięcia PSA 4 ng/ml. W 20-letniej obserwacji wykryto więcej raków w grupie badanej niż kontrolnej odpowiednio 5,7\% i 3,9\%. Nie stwierdzono statystycznie znamiennej różnicy w śmiertelności z powodu raka w obu grupach. Wyniki kwestionowano z powodu małej grupy badanych — tylko 895 miało oznaczane PSA w grupie badanej [18]

\section{Badanie Stockholm}

Prowadzone od 1988 roku objęło 2374 mężczyzn w grupie badanej i 24772 w grupie kontrolnej w wieku 55-70 lat. Badanie DRE, TRUS i PSA wykonywano na każdej wizycie, a biopsję stercza przy PSA > 10 ng/ml.W 12,9-letniej 
średniej obserwacji ryzyko zgonu w grupie badanej było wyższe $(R R=1,10)$ Nie stwierdzono pozytywnego efektu skriningu. Wyniki kwestionowano z powodu małej grupy badanych i wysokiego punktu odcięcia PSA kwalifikującego do biopsji [19].

\section{Badanie Goeteborg}

Prowadzone od 1994 roku we współpracy z ERSPC, objęło po 9952 mężczyzn w obu grupach w wieku 50-64 lata. Badanie z oznaczeniem PSA co 2 lata, punkt odcięcia PSA 2,5-3,4 ng/ml. W 14-letniej obserwacji wykryto więcej raków w grupie badanej niż kontrolnej: odpowiednio 11,4\% i 7,2\%. Uzyskano redukcję śmiertelności z powodu RS o 44\%. W grupie badanej odsetek badanych z niższym zaawansowaniem klinicznym i rzadziej występującymi przerzutami był znamiennie niższy. Wyniki kwestionowano z powodu relatywnie małej grupy i młodego wieku badanych. Mocną stroną metodologii badania były długi czas obserwacji i niewielka kontaminacja [20].

\section{Badanie PLCO (Prostate, Lung, Colon, Ovary skrining trial)}

Prowadzone od 1993 roku, objęło po 38340 mężczyzn w obu grupach w wieku 55-74 lata. Badanie z oznaczeniem PSA co roku przez 6 lat, punkt odcięcia PSA $4 \mathrm{ng} / \mathrm{ml}$. Badanie DRE przeprowadzano co roku przez 4 lata. Nie stwierdzono statystycznie znamiennej różnicy w śmiertelności z powodu raka w obu grupach. Ujemne strony badania to czas obserwacji, wysoka kontaminacja i wykonanie biopsji tylko u 1/3 kwalifikujących się badanych [21]. PLCO było badaniem słabym, przedwcześnie opublikowanym (44\% uczestników miało oznaczone PSA przed włączeniem do skriningu), porównywało skrining intensywny z mało intensywnym. Wyniki były sprzeczne z wynikami ERSPC.

\section{Badanie ERSPC (European Randomized Study of Skrining for Prostate Cancer)}

Rozpoczęte w roku 1991, obejmowało ponad 160 tys mężczyzn z 8 krajów Europy (Belgia, Finlandia, Francja, Włochy, Holandia, Hiszpania, Szwecja, Szwajcaria). Średni wiek wynosił 55-69 lat, a średni czas obserwacji - 14 lat. W badaniu tym mężczyźni zostali zrandomizowami do 2 ramion: ramienia skriningowego (72 891 — zapadalność 8,2\%; 299 zgonów) oraz ramienia kontrolnego (89 352 — zapadalność 4,8\%, 462 zgony). Przyjęto odstęp pomiędzy badaniami skriningowymi poziomu PSA na 4 lata (w Szwecji 2 lata) oraz próg PSA, przy którym kwalifikowano do biopsji na $>3 \mathrm{ng} / \mathrm{ml}$. Jako wynik badania w obserwacji 11-letniej mężczyzn będących w ramieniu skriningowym i grupie wiekowej 55-69 lat stwierdzono redukcję zgonów o 21\% oraz redukcję częstości paliatywnej radioterapii o 35\%. W przypadku skumulowanego ryzyka śmierci z powodu raka stercza w 14-letniej obserwacji stwierdzono redukcję zgonów o 44\%. W badaniu ERSPC stwierdzono nadwykrywalność raka stercza: $69 \%$ raków stercza było w stadium T1 oraz 62\% z Gleason score < 7 [22].

Różnice w wynikach obu badań były przedmiotem kolejnych opracowań, których wnioski sprowadzają się do stwierdzenia, że konstrukcja badań i czas obserwcji były różne. W badaniu PLCO była duża kontaminacja, a badanie ERSPC wykazało, że wraz z wydłużaniem czasu obserwacji rosła przewaga na korzyść grupy badanej $[25,26]$.

\section{Metaanaliza Djulbegovica}

Przedstawiona w 2010 roku, objęła 387286 mężczyzn z 6 randomizowanych badań klinicznych i wykazała blisko $50 \%$ wzrost rozpoznania RS w grupie badanej oraz blisko dwa razy więcej rozpoznań RS w I stopniu klinicznym w tej grupie niż w grupie kontrolnej. Ryzyko zgonu w grupie badanej było niższe $(\mathrm{RR}=0,88)$ [27].

\section{Systemowy przegląd Cochrane}

Przedstawiony w 2006 roku, objął 341351 mężczyzn z 5 randomizowanych badań klinicznych i nie wykazał statystycznie znamiennej różnicy w śmiertelności z powodu raka w obu grupach. W dyskusji podniesiono, że różna jakość i dobór badań mógł wpłynąć na wynik końcowy [28].

\section{Metaanaliza Lumena}

Przedstawiona w 2012 roku objęła 571594 mężczyzn z 8 randomizowanych badań klinicznych i wykazała w grupie badanej 55\% wzrost rozpoznania RS i ponad $80 \%$ wzrost rozpoznań RS w I stopniu klinicznym. Dalsza analiza 4 jednakowo zaplanowych badań wykazała, że ryzyko zgonu w grupie badanej było niższe o 24\% [29].

Wnioski z badań: zmniejszenie śmiertelności zależnej od raka stercza postępuje wraz z czasem trwania obserwacji. O ile po 9-letniej obserwacji należy obserwować 1410 mężczyzn i leczyć 48, by zapobiec 1 zgonowi z powodu RS, to w obserwacji 14-letniej 293 mężczyzn należy leczyć 12, by zapobiec 1 zgonowi z powodu RS [20, 22]. Jest jeszcze za wcześnie, aby przewidywać, kiedy i na jakim poziomie ustabilizuje się redukcja śmiertelności zależnej od raka stercza. Występują interesujące różnice pomiędzy różnymi ośrodkami i badaniami, co sugeruje, że efekt skriningu zależy od innych, jeszcze niezidentyfikowanych zmiennych. Porównując wyniki badania ERSPC ze skriningiem w raku piersi u kobiet: zmniejszenie ryzyka zgonu z powodu raka stercza o 29\%, zmniejszenie ryzyka choroby rozsianej o 35\%. Żeby zapobiec 1 zgonowi z powodu raka stercza: 293 mężczyzn z grupy wiekowej 55-69 lat powinno być poddanych skriningowi, a 12 mężczyzn musi być leczonych. Żeby zapobiec 1 zgonowi z powodu raka piersi: 1000 kobiet powinno zostać poddanych skriningowi, a 10 kobiet musi być leczonych [30]. Czy zrezygnujemy z mammografii? Doniesienia oparte na materiale minionych dwóch dekad wykazują też ujemne 
strony skriningu RS [31, 32]. Carlsson, analizując badanie Goeteborg, wykazał, że w grupie chorych poddanych radykalnej prostatektomii, aby zapobiec 1 zgonowi z powodu raka, narażamy 1 chorego na nietrzymanie moczu, a 4 - na zaburzenia potencji [33]. Liczba powikłań związanych z niepotrzebną biopsją ulega zmniejszeniu z powodu lepszej prewencji i ograniczeniu liczby nieuzasadnionych biopsji [2, 34].

W 2011 roku w najbardziej poczytnych gazetach codziennych w USA (dnia 6 listopada 2011 roku w International Herald Tribune oraz dnia 7 listopada 2011 roku w The New York Times) pojawiły się artykuły opisujące stanowisko panelu specjalistów niezalecających badań przesiewowych w kierunku raka stercza u zdrowych, bezobjawowych mężczyzn. Artykuły zostały oparte na przeglądzie wyników badań opracowanych przez U.S. Preventive Service Task Force (USPSTF), w którego wnioskach czytamy: Skrining oparty na oznaczeniu PSA prowadzi do małej lub żadnej redukcji w śmiertelności zależnejod raka stercza i wiąże się ze szkodami wwyniku dalszego leczenia i ewolucji choroby, z których część może być niepotrzebna [34]. Nie zostały wzięte pod uwagę wyniki efektu skriningu PSA w amerykańskim badaniu SEER, gdzie wykazano redukcję śmiertelności zależnej od raka stercza o $37 \%$ [1].

\section{Zalecenia dotyczące badań przesiewowych w raku stercza}

Zalecenia w USA z roku 2011:USPSTF — nie wykonywać badań przesiewowych; AAFP — nie badać > 75 rż.; ACS i NCCN — dyskusja o zysku i ryzyku. W roku 2012 doszło do zmiany stanowiska USPSTF - dopuszcza ona skrining indywidualny u świadomych mężczyzn. Nowe otwarcie w skriningu RS w 2013 roku proponują towarzystwa urologiczne. AUA rekomenduje skrining u dobrze poinformowanych mężczyzn, rozpoczęcie po 40 rż. [35]. Zalecenia EAU na rok 2013 dotyczące skriningu w raku stercza to skrining powszechny - bezobjawowi mężczyźni, wiek 50-70 lat, wyższe ryzyko (dziedziczność, rasa) oraz skrining oportunistyczny — obejmuje indywidualne postępowanie, inicjowany przez pacjenta i/lub lekarza. Punktami końcowymi obu typów skriningu była redukcja śmiertelności z powodu raka stercza i jakość życia wyrażona zyskiem w latach życia [2]. Celem skriningu nie jest wykrycie większej ilości raków. Nadal pozostają otwarte 2 kluczowe pytania: w jakim wieku rozpocząć badanie? Jak długie powinny być przerwy pomiędzy badaniami (DRE i PSA)?

Aktualne zalecenia EUA na rok 2013: oznaczenie PSA w 40 rż - podstawa do określenia przerw pomiędzy badaniami; gdy PSA $<1,0$, to wystarczająca przerwa wynosi 8 lat. Oznaczenie PSA > 75 rż. - niezalecane.

\section{Ocena indywidualnego ryzyka i nomogramy}

W zastosowaniu i dostępne dla każdego w internecie są kalkulatory ryzyka pozwalające określić grupę podwyż- szonego ryzyka osób będących kandydatami do biopsji [36]. W kalkulacji bierze się pod uwagę poziom PSA, wiek, oczekiwany czas życia, choroby współistniejące, wywiad rodzinny, rasę. Nowe otwarcie w celu poprawy wydolności skriningu obejmuje: poprawę protokołu skriningu (wiek, oznaczenie PSA, częstość oznaczeń, wartość PSA kwalifikująca do biopsji, chemoprewencja, zmiana stylu życia), poprawę obrazowania raka stercza (mpMRI poprawa wykrywalności z 30 do 59\% i poprawa,stagingu” o 44\%) [2, 37].

W kwalifikacji do biopsji mpMRI pozwala uniknąć jej w 42\% przypadków podejrzenia raka stercza, podobnie jak mammografia u kobiet!

W celu poprawy wydolności skriningu może pomóc włączenie nowych czynników prognostycznych (kalikerina, proPSA, PCA 3, TMPPRSS-ERG gen fusion, markery histologiczne w bioptatach), poprawa obrazowania stercza (mpMRI, biopsja celowana pod kontrolą MRI, elastografia USG, PET-cholina. W przeszłości w celu oszacowania ryzyka rozwoju raka stosowano poziom odcięcia PSA, PSAD, PSAV i w przypadku oszacowania podwyższonego ryzyka wykonywano biopsję. Obecnie w celu oszacowania ryzyka stosuje się nomogramy, kalkulatory ryzyka, i w przypadku wystąpienia biologicznie istotnego ryzyka wykonuje się biopsje. Przewiduje się, że w przyszłości będziemy stosować indywidualną ocenę ryzyka, oceniać poziom PSA w wieku 40-60 lat oraz korzystać z testów genetycznych. W przypadku wystąpienia biologicznie istotnego ryzyka wykonywana będzie selektywna biopsja (Kleine — smarter skrining) [38].

Aktualnie wyzwanie dla skriningu RS to zmniejszenie nadwykrywalności i ograniczenie nadmiernego leczenia oraz wynikających z tego powikłań. Aby to osiągnąć, należy: rozdzielić wykrywanie od leczenia, rozwinąć algorytmy do zidentyfikowania raka o niskim stopniu ryzyka, rozwinąć metody aktywnej obserwacji w celu utrzymania chorych „niskiego ryzyka” w okresie wyleczalności aż do czasu konieczności leczenia, odkryć predyspozycje genetyczne i zidentyfikować mężczyzn „wysokiego ryzyka” - może to umożliwić rozwój profilowania z użyciem polimorfizmu pojedynczego nukleotydu (SNP). Ponadto należy odczekać na zakończenie trwających aktualnie badań w celu interpretacji wyników i ostatecznych wyników leczenia oraz odkryć nowe, wiarygodne biomarkery (diagnostyczne, predykcyjne i prognostyczne). Należy edukować lekarzy i potencjalnych pacjentów. To nowe podejście do skriningu RS wymaga odpowiedzi na szereg pytań.

\section{Co nas czeka w przyszłości — dokąd zmierzamy?}

Uwzględnić należy identyfikację kolejnych genetycznych wariantów podwyższonego ryzyka, celowany skrining (zaplanowany indywidualnie) i badania kliniczne, badanie nowych markerów oraz celowane terapie lekowe. Czy decydować się na skrining indywidualny? Jakie są argumenty dla mężczyzn za wczesnym wykryciem raka stercza w skriningu? 
Jeżeli wynik PSA jest prawidłowy, zmniejszy to niepokój związany z rakiem stercza. Badanie poziomu PSA może pomóc w wykryciu raka stercza we wczesnej fazie przed wystąpieniem powikłań. W przypadku dodatniego wyniku biopsji stercza i rozpoznania raka jako wynik oznaczenia PSA chory może zostać poddany leczeniu i żyć dłużej oraz może w przypadku skutecznego leczenia uniknąć cierpienia z powodu choroby rozsianej [40]. Jaki jest wpływ skriningu na jakość życia (QoL)? Mężczyzna jest zadowolony, póki wynik skriningu jest negatywny. W przypadku wykrycia raka stercza podczas skriningu mężczyzna jest wdzięczny, że może być leczony radykalnie w odpowiednim czasie. Aktualnie w USA jest 1878 robotów chirurgicznych da Vinci (2012), i prostatektomia stanowi $80 \%$ wykonywanych operacji robotowych, a zabiegi te wiążą się z minimalizacją występowania powikłań operacyjnych.

Jak rozmawiać z mężczyznami, którzy chcą uczestniczyć w skriningu? Aktualnie około $30-50 \%$ populacji męskiej w wieku 50-80 lat zna własny poziom PSA, często mając oznaczony poziom PSA bez udzielenia świadomej zgody i pełnego zrozumienia, w jakim celu mieli to badanie wykonane $[2,40]$. Ważne jest udzielenie informacji dobrej jakości, w pełni zrozumiałej dla pacjenta i zależnej od wyznawanych przez niego wartości. Najważniejszą rolę w informowaniu pacjenta o skriningu spełnia lekarz prowadzący.

\section{Podsumowanie}

Jakie są mocne argumenty popierające skrining w raku stercza? Rak stercza jest przyczyną śmierci około 3-5\% mężczyzn w Europie. Ze względu na lepszą jakość życia i dłuższy oczekiwany czas przeżycia u mężczyzn skutkuje tym, że większa liczba mężczyzn zachoruje i umrze z powodu raka stercza. A trzeba wyraźnie powiedzieć, że jedynie przypadki raka stercza wykryte w skriningu są wyleczalne. Przypadki wykryte z powodu wystąpienia objawów klinicznych są w większości zbyt zaawansowane, żeby mogły być wyleczone. Dodatkowo leczenie w przypadkach zaawansowanych tylko nieznacznie poprawia wyleczalność, natomiast jest bardzo kosztowne. W ciągu ostatniej dekady objawy uboczne leczenia radykalnego uległy znacznemu zmniejszeniu i są w przypadku wczesnego raka stercza na poziomie akceptowalnym przez mężczyzn. Wyniki skriningu w raku stercza w zmniejszeniu śmiertelności są dobre, lepsze niż w przypadku skriningu raka piersi i raka jelita grubego. Prawdziwy poziom „przediagnozowania”, czyli wykrycia w skriningu raków stercza, które nigdy nie doprowadziłyby do pojawienia się objawów klinicznych, jeżeli pozostałyby bez rozpoznania, do tej pory nie jest znany. Trzeba również powiedzieć, że skrining PSA wyprzedza postawienie rozpoznania o wiele lat, co powoduje, że mężczyzna leczony z powodu wczesnego, czy bardzo wczesnego RS musi poświęcić wiele lat (około 5-10) bezobjawowych za lata z prawdopodobnymi objawami ubocznymi leczenia radykalnego. Stan ten może poprawić skrining indywidualny i dobra informacja dla potencjalnych pacjentów.

\section{Prof. dr hab. n. med. Andrzej Stelmach}

Centrum Onkologii - Instytut

im. Marii Skłodowskiej-Curie

ul. Garncarska 11, 31-115 Kraków

e-mail: stelmachaw@poczta.onet.pl

\section{Piśmiennictwo}

1. American Cancer Society. Global cancer facts \& figures, $2^{\text {nd }}$ Edition. Atlanta: American Cancer Society; 2011.

2. Heidenreich A i wsp. European Association Urology Guidelines. Edition 2013, 1-162.

3. Roobol MJ. Is prostate cancer screening bad or good? Summary of debate at the innovation in urology meeting, September 17-19, 2010, Milan, Italy. Eur Urol 2011; 59: 359-362.

4. Sakr WA, Grignon DJ, Crissman JD i wsp. HGPIN and prostatic adenocarcinoma. An autopsy 249 cases. In Vivo 1994; 8: 439-443.

5. Krajowy Rejestr Nowotworów, Instytut Onkologii, Warszawa, 2008.

6. Nelson WG i wsp. Clinical Oncology, Elselvier 2004; 2085-2149.

7. Eggener S. Prostate cancer diagnosis. 2013; 39-63

8. Collin SM i wsp. Prostate-cancer mortality in the USA and UK in 1975-2004: an ecological study. Lancet Oncol 2008; 9: 445-452.

9. American Joint Committee on Cancer, Cancer Staging Manual, Springer, 2010, 457-468.

10. Catalona WJ, Smith DS, Ratliff TL i wsp. Comparison of digital rectal examination and serum prostate specific antigen in early detection of prostate cancer: results of multicenter clinical trial of 6,630 men. J Urol 1994; 151: 1283-1290.

11. Strope SA, Andriole GL. Prostate cancer screening: current status and future perspectives. Nat Rev Urol 2010; 7; 487-493.

12. Shao YH, Demissie K, Shih W i wsp. Contemporary risk profile of prostate cancer in the United States. J Nat/ Cancer Inst 2009; 101: 1280-1283.

13. Oliver SE, May MT, Gunnell D. International trends in prostate-cancer mortality in the "PSA ERA". Int J Cancer 2001; 92: 893-898.

14. Thompson II, Pauler DK, Goodman PJ i wsp. Prevelance of prostate cancer among man with PSA level < or $=4 \mathrm{ng} / \mathrm{l}$. N Engl J Med 2004; 350: 2239-2246.

15. Bartsch G, Horninger W, Klocker H i wsp. Prostate cancer mortality after introduction of prostate-specific antigenmass screening in the Federal State of Tyrol, Austria. Urology 2001; 58: 417-424.

16. Oberaigner $W$, Siebert $U$, Horninger W i wsp. Prostate-specific antigen testing in Tyrol, Austria: prostate cancer mortality reduction was supported by an update with mortality data up to 2008. Int J Public Health 2012; 57: 57-62.

17. Labrie F, Candas B, Cusan Li wsp. Screening decreases prostate cancer mortality: 11-year follow-up of the 1988 Quebec prospective randomized controlled trial. Prostate 2004; 59: 311-318.

18. Sandblom G, Varenhorst E, Rosell J i wsp. Randomised prostate cancer screening trial: 20 year follow-up. BMJ 2011; 342: d1539.

19. Kjellman A, Akre O, Norming U i wsp. 15-year follow up of a population based prostate cancer screening study. J Urol 2009; 181: 1615-1621.

20. Hugosson J, Carlsson S, Aus G i wsp. Mortality results from the Goteborg randomised population-based prostate-cancer screening trial. Lancet Oncol 2010; 11: 725-732.

21. Andriole GL, Crawford ED, Grubb RL 3rd i wsp. Prostate cancer screening in the randomized Prostate, Lung, Colorectal, and Ovarian Cancer Screening trial: mortality results after 13 years of follow-up. J Natl Cancer Inst 2012; 104: 125-132.

22. Schroder FH, Hugosson J, Roobol MJ i wsp. Prostate-cancer mortality at 11 years of follow-up. N Engl J Med 2012; 366: 981-990.

23. Klotz L, Zhang L, Lam A i wsp. Clinical results of long-term follow-up of a large, active surveillance cohort with localized prostate cancer. J Clin Oncol 2010; 28: 126-131.

24. Soloway MS, Soloway CT, Eld efrawy A i wsp. Careful selection and close monitoring of low-risk prostate cancer patients on active surveillance Eur Urol 2010; 58: 831-835.

25. Schroder FH, Roobol MJ. ERSPC and PLCO prostate cancer screening studies: what are the differences? Eur Urol 2010; 58: 46-52.

26. Berg CD. The Prostate, Lung, Colorectal and Ovarian Cancer Screening Trial: the prostate cancer screening results in context. Acta Oncol 2011; 50 (Suppl 1): 12-17. 
27. Djulbegovic M, Beyth RJ, Neuberger MM i wsp. Screening for prostate cancer: systematic review and meta-analysis of randomised controlled trials. BMJ 2010; 341; c4543.

28. Ilic D, O'Connor D, Green S i wsp. Screening for prostate cancer: an updated Cochrane systematic review. BJU Int 2011; 107: 882$-891$.

29. Lumen N, Fonteyne V, De Meerleert G i wsp. Population screening for prostate cancer: an overview of available studies and meta-analysis. Int J Urol 2012; 19: 100-108.

30. Schroder FH, SIU 2012, Fukuoka. Van Leeuwen PJ i wsp. Prostate cancer mortality in screen and clinically detected prostate cancer: estimating the screening benefit. Eur J Cancer 2010; 46: 377-383.

31. Welch HG, Black WC. Overdiagnosis in cancer. J Nat I Cancer Inst 2010; 102: 605-613.

32. Carlsson S, Aus G, Bergdahl S i wsp. The excess burden of side-effects from treatment in men allocated to screening for prostate cancer. The Goteborg randomised population-based prostate cancer screening trial. Eur J Cancer 2011; 47: 545-53.
33. Roberts RO, Bergstralh EJ, Besse JA i wsp. Trends and risk factors for prostate biopsy complications in the pre-PSA and PSA eras, 1980 to 1997. Urology 2002: 59; 79-84.

34. MoyerVA, on behalf of the U.S. Preventive Services Task Force. Screening for prostate cancer:.U.S. Preventive Services Task Force recommendation statement. Ann Intern Med 2012; 157: 120-134.

35. Brawley OW, Gansler T. Introducing the 2010 American Cancer Society prostate cancer screening guideline. CA Cancer J Clin 2010; 60: 68-69.

36. ERSPC risk calculator.

37. Barentsz JO, Richenberg J, Clements R i wsp. ESUR prostate MR guidelines 2012. Eur Radiol 2012; 22: 746-757.

38. Kleine E. AUA 2013 San Diego

39. Van Leeuwen PJ, Connolly D, Gavin A i wsp. Prostate cancer mortality in screen and clinically detected prostate cancer: estimating the screening benefit. Eur J Cancer 2010; 46: 377-383.

40. Burford DC, Austoker KM. Prostate cancer risk management programme information for primary care: PSA testing in asymptomatic men. Evidence document. NHS Cancer Screening Programmes, 2010.

\title{
W dniu 4 października 2014 r. w Warszawie odbędzie się \\ Konferencja Naukowo-Szkoleniowa "Czerniak i inne nowotwory skóry — postępy w diagnostyce i leczeniu"
}

Konferencja organizowana jest we współpracy z Centrum Onkologii — Instytutem im. Marii Skłodowskiej-Curie w Warszawie i Polskim Towarzystwem Chirurgii Onkologicznej oraz jego sekcją Akademią Czerniaka, która działa m. in. pod patronatem Polskiego Towarzystwa Onkologii Klinicznej, Polskiego Towarzystwa Onkologicznego, Polskiego Towarzystwa Patologów oraz Polskiego Towarzystwa Dermatologicznego.

Interdyscyplinarna konferencja przeznaczona jest dla onkologów, dermatologów i chirurgów. Podczas spotkania omawiane będą postępy w diagnostyce, profilaktyce i terapii nowotworów skóry. Organizatorzy przewidują, że udział weźmie ok. 300 lekarzy.

Konferencję poprzedzi sympozjum nt. dermatoskopii, które odbędzie się w piątek 3 października 2014 r. w godzinach popołudniowych. W sympozjum wezmą udział wysokiej klasy specjaliści. Spotkanie przeznaczone jest dla lekarzy zainteresowanych dermatoskopią. Liczba miejsc jest limitowana. Spodziewamy się udziału 100 osób.

\author{
Przewodniczący Komitetu Organizacyjnego \\ Prof. dr hab. med. Piotr Rutkowski \\ Szczegółowe informacje: \\ http://dermatoonkologia2014.skolamed.pl
}

